\title{
Front Matter: Volume 9101
}

, "Front Matter: Volume 9101," Proc. SPIE 9101, Next-Generation Spectroscopic Technologies VII, 910101 (10 June 2014); doi: 10.1117/12.2069552

SPIE Event: SPIE Sensing Technology + Applications, 2014, Baltimore, MD, United SPIE. States 


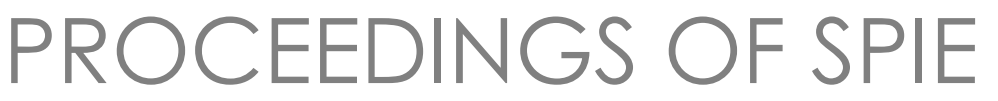

\section{Next-Generation Spectroscopic Technologies VII}

Mark A. Druy

Richard A. Crocombe

Editors

\section{5-6 May 2014}

Baltimore, Maryland, United States

Sponsored and Published by

SPIE 
The papers included in this volume were part of the technical conference cited on the cover and title page. Papers were selected and subject to review by the editors and conference program committee. Some conference presentations may not be available for publication. The papers published in these proceedings reflect the work and thoughts of the authors and are published herein as submitted. The publisher is not responsible for the validity of the information or for any outcomes resulting from reliance thereon.

Please use the following format to cite material from this book:

Author(s), "Title of Paper," in Next-Generation Spectroscopic Technologies VII, edited by Mark A. Druy, Richard A. Crocombe, Proceedings of SPIE Vol. 9101 (SPIE, Bellingham, WA, 2014) Article CID Number.

ISSN: 0277-786X

ISBN: 9781628410389

Published by

SPIE

P.O. Box 10, Bellingham, Washington 98227-0010 USA

Telephone +1 3606763290 (Pacific Time) · Fax +1 3606471445

SPIE.org

Copyright (C) 2014, Society of Photo-Optical Instrumentation Engineers.

Copying of material in this book for internal or personal use, or for the internal or personal use of specific clients, beyond the fair use provisions granted by the U.S. Copyright Law is authorized by SPIE subject to payment of copying fees. The Transactional Reporting Service base fee for this volume is $\$ 18.00$ per article (or portion thereof), which should be paid directly to the Copyright Clearance Center (CCC), 222 Rosewood Drive, Danvers, MA 01923. Payment may also be made electronically through CCC Online at copyright.com. Other copying for republication, resale, advertising or promotion, or any form of systematic or multiple reproduction of any material in this book is prohibited except with permission in writing from the publisher. The CCC fee code is 0277-786X/14/\$18.00.

Printed in the United States of America.

Publication of record for individual papers is online in the SPIE Digital Library.

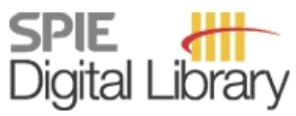

SPIEDigitalLibrary.org

Paper Numbering: Proceedings of SPIE follow an e-First publication model, with papers published first online and then in print and on CD-ROM. Papers are published as they are submitted and meet publication criteria. A unique, consistent, permanent citation identifier (CID) number is assigned to each article at the time of the first publication. Utilization of CIDs allows articles to be fully citable as soon as they are published online, and connects the same identifier to all online, print, and electronic versions of the publication. SPIE uses a six-digit CID article numbering system in which:

- The first four digits correspond to the SPIE volume number.

- The last two digits indicate publication order within the volume using a Base 36 numbering

system employing both numerals and letters. These two-number sets start with 00, 01, 02, 03, 04, $05,06,07,08,09,0 A, 0 B \ldots$. 0Z, followed by 10-1Z, 20-2Z, etc.

The CID Number appears on each page of the manuscript. The complete citation is used on the first page, and an abbreviated version on subsequent pages. Numbers in the index correspond to the last two digits of the six-digit CID Number. 


\section{Contents}

$\begin{array}{ll}\text { vii } & \text { Conference Committee } \\ \text { ix } & \text { Introduction }\end{array}$

910102 Development, characterization and application of compact spectrometers based on MEMS with in-plane capacitive drives (Invited Paper) [9101-1] A. Kenda, M. Kraft, A. Tortschanoff, W. Scherf, Carinthian Tech Research AG (Austria): T. Sandner, H. Schenk, Fraunhofer-Institut für Photonische Mikrosysteme (Germany); S. Lüttjohann, A. Simon, Bruker Optik GmbH (Germany)

910103 Fourier transform infrared phase shift cavity ring down spectrometer [9101-2] E. Schundler, D. J. Mansur, R. Vaillancourt, R. Benedict-Gill, S. P. Newbry, J. R. Engel, J. R. Dupuis, OPTRA, Inc. (United States)

$910104 \quad$ Multiple-order staircase etalon spectroscopy [9101-3] M. K. Yetzbacher, C. W. Miller, A. J. Boudreau, M. Christophersen, U.S. Naval Research Lab. (United States); M. J. Deprenger, Tekla Research Inc. (United States)

910105 On-chip random spectrometer [9101-4]

B. Redding, S. F. Liew, R. Sarma, H. Cao, Yale Univ. (United States)

910106 Microplasmas: from applications to fundamentals [9101-5]

O. Nguon, S. Huang, M. Gauthier, V. Karanassios, Univ. of Waterloo (Canada)

910107 Infrared molecular binding spectroscopy realized in sorbent coated microfabricated devices [9101-6]

R. A. McGill, T. H. Stievater, M. W. Pruessner, U.S. Naval Research Lab. (United States);

S. A. Holmstrom, K. Nierenberg, Univ. of Tulsa (United States); R. McGill, V. Nguyen,

D. Park, C. Kendziora, R. Furstenberg, U.S. Naval Research Lab. (United States)

\section{SESSION 2 NOVEL SPECTROMETER TECHNOLOGIES II}

910108 Recent developments towards low-cost MEMS spectrometers (Invited Paper) [9101-7] D. K. K. M. B. Silva, D. Tripathi, H. Mao, J. Antoszewski, B. D. Nener, J. M. Dell, L. Faraone, The Univ. of Western Australia (Australia)

910109 Optical design of MOEMS-based micro-mechatronic modules for applications in spectroscopy [9101-8]

A. Tortschanoff, M. Kremer, Carinthian Tech Research AG (Austria); T. Sandner, FraunhoferInstitut für Photonische Mikrosysteme (Germany); A. Kenda, Carinthian Tech Research AG (Austria) 
9101 OA Compact multispectral photodiode arrays using micropatterned dichroic filters [9101-9] E. V. Chandler, D. E. Fish, Pixelteq, Inc. (United States)

9101 OB Pure rotational spectrometers for trace-level VOC detection and chemical sensing [9101-24]

J. L. Neill, B. J. Harris, R. L. Pulliam, M. T. Muckle, R. Reynolds, D. McDaniel, BrightSpec, Inc. (United States); B. H. Pate, BrightSpec, Inc. (United States) and Univ. of Virginia (United States)

SESSION 3 NOVEL SPECTROMETER TECHNOLOGIES III

9101 OC Advances in miniature spectrometer and sensor development (Invited Paper) [9101-10] J. Malinen, A. Rissanen, H. Saari, P. Karioja, M. Karppinen, T. Aalto, K. Tukkiniemi, VTT Technical Research Ctr. of Finland (Finland)

$91010 \mathrm{O}$ Multivariate optical element platform for compressed detection of fluorescence markers [9101-12]

R. J. Priore, J. A. Swanstrom, CIRTEMO (United States)

9101 OF Low-cost photonic crystals for spectral sensors fabricated using projection lithography [9101-13]

T. C. Garza, J. I. Scholtz, M. J. Gazes, Chromation Partners, LLC (United States); I. Kymissis, Chromation Partners, LLC (United States) and Columbia Univ. (United States); N. K. Pervez, Chromation Partners, LLC (United States)

\section{SESSION 4 LASER SPECTROSCOPY AND LIBS: TECHNOLOGIES AND APPLICATIONS}

$91010 G$ Distributed feedback interband cascade lasers for spectroscopy from 3-6 $\mu \mathrm{m}$ [9101-14] L. Nähle, C. Zimmermann, M. von Edlinger, J. Schevermann, M. Fischer, L. Hildebrandt, J. Koeth, nanoplus Nanosystems and Technologies GmbH (Germany); R. Weih, S. Höfling, M. Kamp, Julius-Maximilians-Univ. Würzburg (Germany)

$9101 \mathrm{OH}$ Current and emerging laser sensors for greenhouse gas sensing and leak detection [9101-15]

M. B. Frish, Physical Sciences Inc. (United States)

910101 The design and performance characterization of a tunable external cavity quantum cascade laser utilizing thermo-optically tuned thin film filters [9101-16]

E. Ma, C. Marshall, J. Kim, R. Sharp, D. Kuehl, RedShift Systems Corp. (United States)

$91010 \mathrm{~J}$ A spectroscopic tool for identifying sources of origin for materials of military interest [9101-17]

A. W. Miziolek, F. C. De Lucia Jr., U.S. Army Research Lab. (United States)

9101 OK Portable real-time alloy identification of metallic wear debris from machinery lubrication systems: laser-induced breakdown spectroscopy versus $x$-ray fluorescence [9101-18] P. Suresh, GasTOPS Ltd. (Canada) 
$9101 \mathrm{OL}$ Approaching the ppb detection limits for copper in water using laser induced breakdown spectroscopy [9101-19]

W. Tawfik, King Saud Univ. (Saudi Arabia) and Cairo Univ. (Egypt); S. Sawaf, King Saud Univ. (Saudi Arabia)

$91010 \mathrm{M}$ Laser-induced breakdown spectroscopy and spectral analysis of improvised explosive materials [9101-20]

A. J. R. Baver, M. P. Farrington, Applied Research Associates, Inc. (United States); K. Sorauf, Regis Univ. (United States); A. W. Miziolek, U.S. Army Research Lab. (United States)

\section{SESSION 5 NOVEL OR PORTABLE INFRARED AND RAMAN SPECTROMETERS I}

910100 Pocket-size near-infrared spectrometer for narcotic materials identification [9101-23]

C. G. Pederson, D. M. Friedrich, C. Hsiung, M. von Gunten, N. A. O'Brien, JDSU Corp. (United States); H.-J. Ramaker, E. van Sprang, M. Dreischor, Toegepaste Industriële Procesbeheersing (Netherlands)

9101 OP Sensitive algorithm for multiple-excitation-wavelength resonance Raman spectroscopy [9101-26]

B. Yellampalle, H.-S. Wu, W. McCormick, M. Sluch, R. Martin, R. Ice, B. E. Lemoff, West Virginia High Technology Consortium Foundation (United States)

$91010 Q$ Advancements in the safe identification of explosives using a Raman handheld instrument (ACE-ID) [9101-27]

J. Arnó, M. Frunzi, M. Kittredge, B. Sparano, Smiths Detection (United States)

\section{SESSION $6 \quad$ NOVEL OR PORTABLE INFRARED AND RAMAN SPECTROMETERS II}

9101 OS A military grade, field usable, Raman analyzer: measurement of captured fuel [9101-30] S. Farquharson, W. Smith, C. Shende, M. Patient, H. Huang, C. Brouillette, Real-Time Analyzers, Inc. (United States)

9101 OT Detection of chemical warfare simulants using Raman excitation at $1064 \mathrm{~nm}$ [9101-31] C. Dentinger, M. W. Mabry, E. G. Roy, Rigaku Raman Technologies (United States)

\section{SESSION $7 \quad$ INNOVATIONS IN IMAGING SPECTROMETERS I}

9101 OV Remote gas plume sensing and imaging with NASA's Hyperspectral Thermal Emission Spectrometer (HyTES). [9101-32]

W. R. Johnson, G. Hulley, S. J. Hook, Jet Propulsion Lab. (United States)

9101 OW Miniaturized handheld hyperspectral imager [9101-33]

H. Wu, F. G. Haibach, E. Bergles, J. Qian, C. Zhang, W. Yang, BaySpec, Inc. (United States)

$91010 X \quad$ High-performance hyperspectral imaging using virtual slit optics [9101-34]

B. B. Behr, Tornado Spectral Systems (United States); Y. Bismilla, A. T. Cenko, B. DesRoches,

J. T. Meade, E. A. Munro, J. Slaa, A. R. Hajian, Tornado Spectral Systems (Canada) 
9101 OY Dynamic 3D chemical agent cloud mapping using a sensor constellation deployed on mobile plafforms [9101-35]

B. R. Cosofret, D. Konno, D. Rossi, W. J. Marinelli, P. Seem, Physical Sciences Inc. (United States)

$91010 Z$ LWIR hyperspectral micro-imager for detection of trace explosive particles [9101-36] A. L. Bingham, Spectrum Photonics, Inc. (United States); P. G. Lucey, Spectrum Photonics, Inc. (United States) and Univ. of Hawaili at Manoa (United States); J. T. Akagi, J. L. Hinrichs, E. T. Knobbe, Spectrum Photonics, Inc. (United States)

910110 A compact Fourier transform imaging spectrometer employing a variable gap Fabry-Perot interferometer [9101-37]

P. G. Lucey, Univ. of Hawaili at Manoa (United States); J. Akagi, A. L. Bingham, J. L. Hinrichs, E. T. Knobbe, Spectrum Photonics, Inc. (United States)

\section{SESSION $8 \quad$ INNOVATIONS IN IMAGING SPECTROMETERS II}

910111 Adaptive hyperspectral imaging with a MEMS-based full-frame programmable spectral filter [9101-38]

D. L. Graff, S. P. Love, Los Alamos National Lab. (United States)

Author Index 


\title{
Conference Committee
}

\author{
Symposium Chair
}

David A. Whelan, Boeing Defense, Space, and Security (United States)

Symposium Co-chair

Wolfgang Schade, Technische Universität Clausthal (Germany) and

Fraunhofer Heinrich-Hertz-Institut (Germany)

\section{Conference Chairs}

Mark A. Druy, Physical Sciences Inc. (United States)

Richard A. Crocombe, Thermo Fisher Scientific Inc. (United States)

\section{Conference Program Committee}

Leigh J. Bromley, Daylight Solutions Inc. (United States)

John M. Dell, The University of Western Australia (Australia)

Richard D. Driver, Headwall Photonics Inc. (United States)

Michael B. Frish, Physical Sciences Inc. (United States)

Fredrick G. Haibach, Block Engineering, LLC (United States)

Martin Kraft, Carinthian Tech Research AG (Austria)

Jouko O. Malinen, VTT Technical Research Center of Finland (Finland)

Curtis A. Marcott, Light Light Solutions, LLC (United States)

Ellen V. Miseo, Analytical Answers, Inc. (United States)

David W. Schiering, Smiths Detection (United States)

John Seelenbinder, Agilent Technologies (United States)

\section{Session Chairs}

1 Novel Spectrometer Technologies I

Mark A. Druy, Physical Sciences Inc. (United States)

2 Novel Spectrometer Technologies II

Richard A. Crocombe, Thermo Fisher Scientific Inc. (United States)

3 Novel Spectrometer Technologies III

Richard A. Crocombe, Thermo Fisher Scientific Inc. (United States)

4 Laser Spectroscopy and LIBS: Technologies and Applications

Leigh J. Bromley, Daylight Solutions Inc. (United States) 
5 Novel or Portable Infrared and Raman Spectrometers I

Richard A. Crocombe, Thermo Fisher Scientific Inc. (United States)

6 Novel or Portable Infrared and Raman Spectrometers II

Mark A. Druy, Physical Sciences Inc. (United States)

7 Innovations in Imaging Spectrometers I

Richard A. Crocombe, Thermo Fisher Scientific Inc. (United States)

8 Innovations in Imaging Spectrometers II

Mark A. Druy, Physical Sciences Inc. (United States) 


\section{Introduction}

The past twenty-five years have seen a massive investment in photonics, electronics and MEMS, aimed at developing new telecommunications capabilities and innovative consumer products. This has led to advances in miniature optics, light sources, tunable filters, array detectors, fiber optic sensors, and a range of other photonic devices, across the whole electromagnetic spectrum, along with technologies for their mass production. Similarly, in recent years, there have been remarkable developments in handheld consumer electronics, especially cell phones and portable audio/video players. Today's devices contain advances in RF technology, processors, operating systems, user interfaces, memory, Bluetooth, WiFi, GPS, cameras, accelerometers, etc. These technologies are increasingly being exploited in new spectroscopic instruments, and are now poised to be the basis of next-generation handheld scientific instruments.

Portable and handheld instruments are being developed that are more targeted at specific applications than their laboratory predecessors. They may have performance (measured as resolution, spectroscopic range, signal-to-noise, etc.) that is 'good enough' for field screening applications. However, they are often more selective, smaller, cheaper, and more robust.

Concurrent improvements in analytical theory, data analysis methods, algorithms and the power of portable processors enable these spectroscopic devices to give specific actionable answers to their non-specialist operators. Spectroscopybased systems are now making critical judgments in environments and applications that were unreachable twenty years ago, from hazardous materials to the operating theater, and from field geologists to customs and border personnel.

Advances in array detectors (CCD, CID, InGaAs, InSb, MCT, CMOS, etc.) are enabling a new generation of faster imaging spectrometers, with both laboratory and field applications. Lower-cost infrared arrays have been developed, employing MEMS techniques. New laser sources, particularly in the mid-infrared, are being used in combination with advances in detector technology to create new spectroscopic platforms.

The emphasis in this conference is on advanced technologies for spectroscopic instrumentation, particularly the infrared, near-infrared, and Raman molecular techniques, but also including advances enabling miniature and portable spectrometers across the electromagnetic spectrum, including $x$-ray fluorescence, laser induced fluorescence, laser induced breakdown spectroscopy (LIBS), Terahertz, nuclear magnetic resonance and mass spectrometry. The conference also includes papers describing breakthrough and 
novel, recently-introduced, commercial instrumentation. For instance, the past year has seen the first true-handheld commercial LIBS instruments, the first truehandheld commercial mass spectrometer and the first QCL-based infrared microscope spectrometer.

This conference premiered at Optics East 2007 in Boston, MA and is now part of the Sensing Technology and Applications Symposium. In 2014, the conference spanned two days, and was divided into sessions focusing on: Novel Spectrometer Technologies; Laser Spectroscopy and LIBS: Technologies and Applications; Novel or Portable Infrared and Raman Spectrometers and Innovations in Imaging Spectrometers. In all, 39 papers were presented, and we present 32 in this volume.

Mark A. Druy Richard A. Crocombe 